\begin{tabular}{c} 
Journal of Business School \\
$2019,2(2): 1-11$ \\
DOI: $10.26677 / T R 1010.2019 .62$ \\
Journal Homepage: https://www.journalbusiness.org \\
\hline
\end{tabular}

\title{
The Effectiveness of Pension Payment Management in Tanzania: A Case of NSSF in Iringa Municipality
}

\author{
Cosmas Ngala \\ Ruaha Catholic University, Tanzania. \\ Hadija Matimbwa \\ Ruaha Catholic University, Tanzania. hadija.matimbwa@gmail.com
}

\begin{abstract}
This study assessed the effectiveness of pension payment management in Tanzania particularly in Iringa Municipality. Specifically, the influence of ICT use, quality of staff and management style on the effectiveness of pension payment management examined. The study attempted to respond to the following research questions: - how do ICT use, quality of staff, and management style adopted contribute to the effectiveness of pension payment management? Study findings derived are imperative to the government of Tanzania, Social Security Regulatory Authority as policy makers, NSSF management, other scholars and academicians intending to venture into similar studies.

The study was conducted at NSSF in Iringa Municipality and was informed by 32 staff who responded to closed-ended questionnaires. The research was a census study implying that it was unnecessary to obtain a specific sample size owing to the fact that the NSSF, which was the focus of the study currently, accommodates only 32 staffs. A descriptive survey design was employed where frequencies and percentages were used to present participant characteristics on tables, figures and charts. The relationships between study variables were determined through the inferential analysis tool that analyzes point to the approach of SPSS version 20. Multiple Linear Regression was used to test hypotheses: the relationship between independent variables and dependent variables. Finally, the researcher tested the validity and reliability of the study using the KMO index which was 0.798 and $\mathrm{p}<0.0005$ and Coefficient Alpha (Cronbach's Alpha) which was 0.884 respectively.

Findings revealed a statistically significant weakly relationship between use of ICT and management style on the effectiveness of pension payment management also the findings revealed a moderate relationship between quality of staff and effectiveness of pension payment management.
\end{abstract}

Keywords: Pension, Payment Management, Tanzania. 


\section{Introduction}

The pre-social security era was characterized by traditional forms of economic security that left most people vulnerable to the uncertainties of unemployment, illness, disability, death and old age. In the realm of economics, these inevitable facets of life are said to pose threats to one's economic security (Dagauda et al, 2013). Families and their relatives have always felt some degree of responsibility to one another to the extent that the family had resources to draw upon; this was often a source of economic security, especially for the aged or infirm. Land itself was an essential form of economic security for those who owned it or lived on farms while other traditional sources of economic security included: assets, labor, family, and charity (Ako, 2006).

The formal social security system in Africa and other developing countries is a product of colonialism. In Tanzania during the colonial era, social security coverage was extended to just a few people in the colonial employment with most excluded from the scheme. The majority of Tanzanians depended on the traditional social security system for their protection, which is still the case to date, though effects of urbanization and difficult economic environment have weakened the same. The post independence era in Tanzania saw to the introduction of a series of policies and measures to reverse the situation that had previously prevailed in the colonial era. The measures included access to free education and healthcare, provision of social welfare services to marginalized groups such as the elderly, people with disabilities and children in difficult circumstances, as well as establishment of statutory social security schemes. However, tax financed social services have proved to be unsustainable as evidenced by introduction of cost sharing in sectors such as education and health (report of Ministry of Labor, Youth Development and Sport, 2003).

According to Kazimoto et al, (2012), the pension sector plays a tremendous role in Tanzania's economy by providing retirees with income security. Furthermore, the pension system in the country is a powerful force in developing capital markets and supports the provision of longterm finance. Also the challenges facing public pension systems in Tanzania are related to inherited institutional designs and resultant governance problems. Service delivery is an area which has generated substantial dissatisfaction among members and other beneficiaries of public pension schemes, lack of updated information about the schemes, the amount of individual contributions made, estimated benefits and the number of benefits offered by most existing schemes fall below the ILO Minimum Standards in terms of number, quality and indexation to the current levels of earnings.

Tanzania's social security pension scheme is also faced with problems and key of these is ineffective pension payment management. Another dimension of the problem is the recent controversial practice of pension funds being directly released to underwriters (Kazimoto et al, 2012). In most cases, management is unaware of some transactions that result in the amount so released. This scenario has further complicated the problem, resulting in accumulated arrears of pensioners. Some retirees fail to comply with requirements, possibly due to the cumbersomeness of the clearance procedures, leading to delay in the processing and payment of their entitlements (Kazimoto et al, 2012).

The ICT system in most social security pension offices in the country is inadequate as files are mishandled, sometimes misplaced, left in the open in ragged leading to loss of documents. Incompetent and inexperienced pension staff with irrelevant training is another difficulty facing the pension payment management scheme in Tanzania further compounded by their poor human relations skills. The continuous petitions and appeals for recalculations and computation of gratuity and pension from pensioners is another predicament. Majority of pensioners are grossly dissatisfied with calculations of their entitlements that they claim are wrongly computed. The fact that majority of pension records are not computerized does not 
help matters as the manual system is not only cumbersome but loaded with all sorts of fraud and errors such as ghost pensioners, double payments and omission of names (Tungaraza et al, 2008). Frequent reviews of pension schemes by the central government without consulting state governments and other stakeholders constitute a major challenge. Frequent reviews have resulted to implementation challenges such as inability to secure sufficient funds to meet current rates. Downsizing and rationalization of personnel in an effort to reduce operational and labor costs and promote efficiency is equally a predicament. The paradox here is that the costs attached to paying retirement and pension benefits are higher than the costs of retaining them and a collection of these many challenges constitutes the research problem.

\section{Literature Review}

\subsection{Relationship between Use of ICT and Pension Payment Management}

Okoli et al, (2012) examined "the influence of ICT on secretaries' performance in government ministries in Nasarawa State" and found that ICT enhanced the proficiency of secretaries by enabling them to process accurate and relevant information within the shortest possible time. The advent of ICT has dramatically changed the roles and effectiveness of secretaries in government offices; hence there is need for availability of ICT resources/equipments in government offices as well as acquisition of secretarial requisite skills and competencies. The study revealed that ICT influenced the performance of secretaries in various ways to include; speedy delivery of information, accuracy and effectiveness at work. The researchers recommended among others that government ministries should procure the latest model of ICT facilities to enhance secretarial functions and create opportunities for training and re-training of secretaries as to cope with new changes and advancement. In the current study issues like speedy delivery of information, accuracy and effectiveness at work were taken for further study.

Sabina (2016) studied the influence of employee motivation strategies on project performance: a case of Information Communication Technology (ICT) transformational project Nairobi county government, Kenya. The Nairobi City Country envisioned that operational improvement through ICT transformation would strengthen the County's ability to improve service quality delivery. This motivated The Nairobi City County Government to embark on an ICT Transformational Project that seeks to deploy suitable ICT solutions at the county headquarters and its satellite offices with the aim of improving citizen service delivery, increasing efficiency and enhancing revenue collection. However ICT use and uptake is yet to meet the intended objective as attributed to employee motivational levels which potentially influences ICT Transformation project performances. It was concluded as per findings that organizational culture change significantly influenced ICT transformational project performance, project motivation strategies influenced the technical satisfaction of customers, budget and resources, provision of quality services, and increased rates of client to a very great extent, team building influence success of ICT transformation project performance and that lack of teamwork in project management affects project performance and that there exists a significant and positive relationship between stakeholder communication and ICT transformational project performance. Therefore in view of the aforementioned strategies and cohesive factors, perspective methods should be adopted to combat wastage of resources and improve project performance in the County government of Nairobi. However; based on this review for current study, the issue of change in organizational culture and improvement of quality of services through use of ICT to enhance the Project Performance in Nairobi City County Government, Kenya also, were taken for further investigation if can be enhancing effectiveness of pension payment management in Tanzania. 
Irungu, (2015) studied the influence of information and communication technology on the performance of the aviation industry in Kenya with the case of Kenya Airways -Kenya offices. Study findings showed that information and communication technology which includes communication networks, mobile phone technology, and handheld devices such as iPads and Internet and computer applications influence the performance of the aviation to a large extent by assisting to improve on speed of passenger handling and increased revenue generated from improved access to information. It was recommended that the company should align itself to using ICT at a strategic level. However; this review was vital on improving the way of handling passenger through using ICT as the current study was further investigating likely issues such as ways of communication and feedback, database management, fraud detection and cost reduction with increase revenue through using ICT on the effectiveness of pension payment management.

\subsection{Relationship between Quality of Staff and Pension Payment Management}

There is a large and growing body of evidence that demonstrates a positive linkage between the quality of employees in terms of skills, knowledge and experience with organizational performance. The emphasis on human capital in organizations reflects the view that the market value depends less on tangible resources, but rather on intangible ones, particularly human resources. Recruiting and retaining the best employees, however is only part of the equation (Cassel, 2001). The organization including pensions fund also has to leverage the skills and capabilities of its employees by encouraging individual and organizational learning and creating a supportive environment where knowledge and skills can be created, shared and applied.

It is believed that the linkage between quality of employees and organizational performance is convincing. Quality of employees was found to improve productivity in terms processing of benefits; investments of pension funds since it encourages innovation to problem solving, achieving competitiveness and mitigating associated costs related to litigation (Lorbiecki, 2000). It was revealed that Quality employees play an important role in strategic planning on how to create competitive advantages. It has two dimensions which are value and uniqueness. Firms indicate that resources are valuable when they allow improving effectiveness, capitalizing on opportunities and neutralizing threats. In the context of effective management, value focuses on increasing profit in comparison to associated costs. In this sense, firm's employees can potentially add value if it contributes to lower costs, provide increased performance and quality services to clients. However; the current study was further re-investigate the following sentences for effectiveness of pension payment management "leverage the skills and capabilities of its employees by encouraging individual and organizational learning and creating a supportive environment where knowledge and skills can be created, shared and applied" (Cassel, 2001) and where Lorbiecki, (2000), "Quality of employees was found to improve productivity in terms processing of benefits; investments of pension funds since it encourages innovation to problem solving, achieving competitiveness and mitigating associated costs related to litigation; also, Quality employees play an important role in strategic planning on how to create competitive advantages of an organization".

\subsection{Relationship between Management Style and Pension Payment Management}

Wairumi (2014) investigated the relationship between employees and employers and found it significantly influence management style that an institution usually employs. It is important to understand the different styles of management that institutions employ and understand the manner in which such styles influence worker motivation. The purpose of this study was to explore the relationship between management styles and worker motivation in Kenya. The researcher reviewed literature from all over the world in order to understand the theoretical perspectives of management and motivational needs at the workplace. 
The research employed a desk study whereby various literature materials from Kenya were researched and compared in order to meet the objectives of the study (Iqbal, 2007). From the results, it was established that most studies done in Kenya on management styles and motivational needs at the workplace were done in teaching institutions and most were conducted students. Only one study was commissioned by an institution to study its employees' motivation. The research concluded that democratic and transformational management styles were the most worker motivational management styles as preferred by most employees. Institutions that employed authoritative and laissez faire styles of management were found to be less motivating and experienced low productivity (Dwivedula \& Bredillet, 2010). It was recommended that future field studies should be commissioned by more institutions in the country in order to ensure that employers understand workers' motivational needs. It is only through such understanding that employers will be able to improve organizational productivity (Greenberg, 2011). However, the current study was interested with the reviews since the reviews advocated that "institutions involved in the study employed authoritative and laissez faire styles of management which found to be less motives to the workers and experienced low productivity" (Dwivedula \& Bredillet, 2010). This scenario provide new room for the current study to investigate further other way(s) of management style such as involvement management style, delegation of power (mutual trust) between top management up to the first line subordinates, two ways communication style and the Administrators provide the direction (setting clear goals) in which the subordinates follow-up to achieve the organizational mission as well as vision.

Namusonge et al (2012) investigated the major effects of leadership styles on organizational performance in state owned corporations in Kenya; specifically the study sought to determine the impact of laissez-faire, transactional and transformational leadership styles on organizational performance at state-owned corporations in Kenya. A descriptive survey research based on the perceptions of middle and senior managers in thirty (30) state-owned corporations based in Mombasa, Kenya was undertaken. A structured self-completed research questionnaire was thereafter distributed and collected after one week. The completed questionnaires were checked for plausibility, integrity and completeness resulting in 72 usable cases. To identify leadership styles that influence organizational performance, a correlation analysis was employed. Correlations between the transformational-leadership factors and organizational performance ratings were high $(0.518$ to $0.696, \mathrm{P}<.05)$, whereas correlations between the transactional-leadership behaviors and organizational performance were relatively low $(0.219$ to $0.375, \mathrm{P}<.05)$. As expected, the laissez-faire leadership style was not significantly correlated to organizational performance thus the following recommendations were provided: managers should discard the laissez-faire leadership style by actively guiding their subordinates; public managers should formulate and implement effective reward \& recognition systems. It was further recommended that managers should: strive to become role models for their subordinates; inspire subordinates by providing meaningful and challenging work; stimulate subordinate efforts to become more innovative \& creative; and lastly, pay greater attention to each individual's need for achievement and growth.

\subsection{Research Gap}

As revealed in literature reviewed, several scholars have studied organizational productivity and performance in consideration of determinants such as use of ICT, quality of staff, management style, working environment, organizational culture and design as well as power control. The following are specific issues from empirical reviews presented above which impressed for further investigation of the study. Firstly; Ajala, (2012) for instance analyzed the influence of the workplace environment on workers welfare and productivity in government parastatals of Ondo State, Nigeria and findings showed that workplace features and good 
communication network at workplaces affected worker's welfare, health, morale, efficiency, and productivity, where the study didn't say about the role or influence of management style in organization(s) on the performance of task(s), where the current study was taken this issue for further investigation; Secondly; some literature reviews on ICT had spoken on the influence on the performance. For example; Okoli et al, (2012) examined the influence of ICT on secretaries' performance in government ministries in Nasarawa State and found that ICT influenced secretaries' performance. The study didn't investigate about others factors such as the effect of use of ICT on the effectiveness at work where also the current study also was investigated.

Thirdly; some of literature reviews communicated about the qualities of employees on working places for example, Lorbiecki, (2000); believed that the linkage between quality of employees and organizational performance is convincing. Quality of employees was found to improve productivity in terms processing of benefits; investments of pension funds since it encourages innovation to problem solving, achieving competitiveness advantages and mitigating associated costs related to litigation. The current study was impressed to redo and move further investigate the issues such as commitment and tolerance of workers, customers services excellence, career growth and competence of workers. However, this study systematically assessed the effectiveness of pension payment management in Tanzania and it should noted that most of the studies have been conducted in other African countries and regions and very few in East African countries like Tanzania, Kenya, Uganda, Rwanda, Burundi and South Sudan thus, the current study attempted to bridge this knowledge gap.

\section{Results and Discussion}

\subsection{Contribution of ICT on the effectiveness of pension payment management}

Upon measuring the contribution of ICT on pension payment management, several indicators were taken into consideration such as data base management, easily processing pension's payment, quickly services delivery, new ways of communication, prompt feedback, cost reduction and fraud detection as indicated on table 1 below.

Table 1 The influence of use of (ICT) on the Effectiveness of Pension Payment Management

\begin{tabular}{|c|c|c|c|c|c|c|c|}
\hline $\begin{array}{l}\text { Use of ICT } \\
\text { Indicators' }\end{array}$ & $\begin{array}{l}\text { Strongly } \\
\text { Disagree }\end{array}$ & Disagree & $\begin{array}{c}\text { Cumulative } \\
\text { Disagree }\end{array}$ & Neutral & Agree & $\begin{array}{l}\text { Strongly } \\
\text { Agree }\end{array}$ & $\begin{array}{c}\text { Cumulative } \\
\text { Agree }\end{array}$ \\
\hline Item & Per(Frq) & $\begin{array}{l}\text { Per } \\
\text { (Frq) }\end{array}$ & Per(Frq) & Per(Frq) & Per(Frq) & Per (Frq) & Per(Frq) \\
\hline $\begin{array}{l}\text { Database } \\
\text { management }\end{array}$ & $0.0(0)$ & $3.1(1)$ & $3.1(1)$ & $0.0(0)$ & $43.8(14)$ & $53.1(17)$ & $96.9(31)$ \\
\hline $\begin{array}{l}\text { Easily pension } \\
\text { processing }\end{array}$ & $0.0(0)$ & $3.1(1)$ & 3.1(1) & $3.1(0)$ & $37.5(12)$ & $56.3(18)$ & $93.8(30)$ \\
\hline $\begin{array}{l}\text { Quickly service } \\
\text { delivery }\end{array}$ & $0.0(0)$ & $0(0)$ & $0.0(0)$ & $3.1(1)$ & $34.4(11)$ & $62.5(20)$ & $96.9(31)$ \\
\hline $\begin{array}{l}\text { New ways of } \\
\text { communication }\end{array}$ & $0.0(0)$ & $0(0)$ & $0.0(0)$ & $6.3(2)$ & $37.5(12)$ & $56.3(18)$ & $93.8(30)$ \\
\hline $\begin{array}{l}\text { Prompt } \\
\text { feedback }\end{array}$ & $0.0(0)$ & $12.5(4)$ & $12.5(4)$ & 3.1(1) & $37.5(12)$ & $46.9(15)$ & $84.4(29)$ \\
\hline Cost reduction & $0.0(0)$ & $3.1(1)$ & $3.1(1)$ & $0.0(0)$ & $40.6(13)$ & $56.3(18)$ & $96.9(31)$ \\
\hline Fraud detection & $0.0(0)$ & $0(0)$ & $0.0(0)$ & $3.1(1)$ & $34.4(11)$ & $62.5(20)$ & $96.9(31)$ \\
\hline
\end{tabular}

Source: Field data (2018)

Table 1 indicates that $96.9 \%$ of respondents declared that the ICT system is effective for database management. Furthermore, $96.9 \%$ of respondents affirmed that the ICT system facilitates quick service delivery and reduces costs during pension payment. Moreover $96.9 \%$ of respondents agreed that ICT systems enable the detection of fraud during pension payment 
while $93.8 \%$ stated that the ICT system facilitates easy processing of pension payment. $93.7 \%$ also suggested that the ICT system creates new ways of communication while $84.4 \%$ agreed that system provides real time. Therefore, these findings above imply that ICT systems help NSSF in managing their data accordingly as well as provide quick services to customers, cost efficient also create new ways of communication. Hence enhance the effectiveness of pension payment management.

The findings are in line with those established by Macintosh et al., (2003) who found that well implemented ICT systems can improve current government services, increase accountability, and results in more accurate and efficient delivery of service, reduce administrative costs and time spend on repetitive tasks for government employees. The above findings are also supported by Adekunle, Oluwole, Binuyo and Tersia Brevis-Landsberg (2014) who assessed the relationship between ICT investments in relation to organizational performance in Nigeria with a specific focus on knowledge-imbibed organizations - universities. The study focused on drawing possible relationships between ICT investment and ICT cost efficiency and, various indicators of organization performance such as return on capital employed, net profit margin and return on assets. The study was informed by data generated from annual reports of 37 universities in South West Nigeria over the period between 2001 and 2010 in dynamic panel environment. Controlling for structural differences and time-varying dynamics among these universities, the analyses show varying effects of ICT investment on performance. The findings also indicate that ICT investment and ICT cost efficiency have a positive and significant relationship with performance indicators. It was recommended that ICT investment should be guided in order to stimulate organizational performance.

\subsection{The Influence of Staff Quality on the Effectiveness of Pension Payment Management}

In an effort to examine the influence of staff quality on pension payment management, several dimensions explored include; creativity, service diversification, hardworking, career development, competitive advantage and customer service excellence and findings are as indicated on 2 below:

Table 2 The Influence of Staff Quality on the Effectiveness of Pension Payment Management

\begin{tabular}{|c|c|c|c|c|c|c|c|}
\hline $\begin{array}{l}\text { Staff Quality } \\
\text { Indicat0rs' }\end{array}$ & $\begin{array}{l}\text { Strongly } \\
\text { Disagree }\end{array}$ & Disagree & $\begin{array}{l}\text { Cumulative } \\
\text { Disagree }\end{array}$ & Neutral & Agree & $\begin{array}{l}\text { Strongly } \\
\text { Agree }\end{array}$ & $\begin{array}{c}\text { Cumulative } \\
\text { Agree }\end{array}$ \\
\hline Item & Per(Frq) & $\begin{array}{l}\text { Per } \\
\text { (Fqr) }\end{array}$ & Per (Frq) & Per(Frq) & $\begin{array}{l}\text { Per } \\
\text { (Frq) }\end{array}$ & Per (Frq) & Per (Frq) \\
\hline $\begin{array}{l}\text { Creativity and } \\
\text { innovativeness }\end{array}$ & $0.0(0)$ & $0.0(0)$ & $0.0(0)$ & $3.1(1)$ & $37.5(12)$ & $59.4(19)$ & $96.9(31)$ \\
\hline $\begin{array}{l}\text { Ability to work } \\
\text { independently }\end{array}$ & $0.0(0)$ & $0.0(0)$ & $0.0(0)$ & $0.0(0)$ & $31.3(10)$ & $68.8(22)$ & $100(32)$ \\
\hline Commitment & $0.0(0)$ & $3.1(1)$ & $3.1(1)$ & $0.0(0)$ & $28.1(9)$ & $68.8(22)$ & $96.9(31)$ \\
\hline Career growth & $0.0(0)$ & $12.5(4)$ & $12.5(4)$ & $0.0(0)$ & $28.1(9)$ & $59.4(19)$ & $87.5(28)$ \\
\hline $\begin{array}{l}\text { Competitive } \\
\text { advantage }\end{array}$ & $0.0(0)$ & $0.0(0)$ & $0.0(0)$ & $0.0(0)$ & $31.3(10)$ & $68.8(22)$ & $100(32)$ \\
\hline $\begin{array}{l}\text { Customer service } \\
\text { excellence }\end{array}$ & $0.0(0)$ & $0.0(0)$ & $0.0(0)$ & $3.1(0)$ & $31.3(0)$ & $65.6(21)$ & $96.9(31)$ \\
\hline Mastering work & $0.0(0)$ & $3.1(1)$ & 3.1(1) & $0.0(0)$ & $43.8(14)$ & 53.1(17) & $96.9(31)$ \\
\hline
\end{tabular}

Source: Field Data (2018) 
Table 2 above shows that $100 \%$ of respondents declared that NSSF Staff have the ability to work independently. It further shows that respondents revealed that stuff are resilient to difficulties, challenges and conflicts from customers or top management and could ensure competitive advantage. $96.9 \%$ of respondents revealed that NSSF Staff were creative, innovative and willing to work hard to ensure effective pension payment management. Furthermore the same percentage of respondents agreed that NSSF staff provide excellent customer service while 93.7\% declared that service diversification depended on staff quality. Finally, $87.5 \%$ of respondents stated that NSSF staffs were willing to develop their career in pension payment management.

Findings therefore imply that staff quality is determined by their creativity, service diversification as well as excellent customer service provision. These findings with similar findings by Dutta et al. (2011) who analyzed whether and how specialized and diversified education influences innovative ideas into entrepreneurship and future wealth. Their findings revealed that quality staff led to higher productivity and creation of sustainable competitive advantage. Moreover Bontis, Keow and Richardson (2000) found a positive significant relationship between employees' level of education and firm performance for both service and non service industries. Carmeli and Tishler (2004) and Belkaoui (2003) proved a positive association between quality of employees and firm future performance and suggested that the relationship might be industry and country specific.

\subsection{The Influence of Management Style on the Effectiveness of Pension Payment Management}

The responses on the influence of management style on the effectiveness of pension payment management are as presented on Table 3 below

Table 3 The Influence of Management Style on the Effectiveness of Pension Payment Management

\begin{tabular}{|c|c|c|c|c|c|c|c|}
\hline $\begin{array}{l}\text { Management } \\
\text { Style } \\
\text { Indicators' }\end{array}$ & $\begin{array}{l}\text { Strongly } \\
\text { Disagree }\end{array}$ & Disagree & $\begin{array}{c}\text { Cumulative } \\
\text { Disagree }\end{array}$ & Neutral & Agree & $\begin{array}{c}\text { Strongly } \\
\text { Agree }\end{array}$ & $\begin{array}{c}\text { Cumulative } \\
\text { Agree }\end{array}$ \\
\hline Item & Per (Frq) & Per (Frq) & Per(Frq) & Per(Frq) & $\begin{array}{l}\text { Per } \\
\text { (Frq) }\end{array}$ & Per (Frq) & Per (Frq) \\
\hline $\begin{array}{l}\text { Availability of } \\
\text { employee goals }\end{array}$ & $0.0(0)$ & $0.0(0)$ & $0.0(0)$ & $0.0(0)$ & $46.9(15)$ & $53.1(17)$ & $100(32)$ \\
\hline $\begin{array}{l}\text { Two way } \\
\text { communication } \\
\text { style }\end{array}$ & $0.0(0)$ & $0.0(0)$ & $0.0(0)$ & $3.1(1)$ & $46.9(15)$ & $50.0(16)$ & $96.9(31)$ \\
\hline Mutual Trust & $0.0(0)$ & $0.0(0)$ & $0.0(0)$ & $3.1(1)$ & $31.3(10)$ & $65.6(21)$ & $96.6(31)$ \\
\hline $\begin{array}{l}\text { Employees } \\
\text { involvement }\end{array}$ & $0.0(0)$ & $6.3(2)$ & $6.3(2)$ & $3.1(1)$ & $53.1(17)$ & $37.5(12)$ & $90.6(29)$ \\
\hline $\begin{array}{l}\text { Provision of } \\
\text { rewards or } \\
\text { motivation }\end{array}$ & $3.1(1)$ & $0.0(0)$ & 3.1(1) & $3.1(1)$ & $53.1(17)$ & $40.6(13)$ & 93.7(30) \\
\hline $\begin{array}{l}\text { Encourages } \\
\text { poor } \\
\text { performers } \\
\end{array}$ & $6.3(2)$ & $34.4(11)$ & 40.7(13) & $3.1(1)$ & $28.1(9)$ & $28.1(9)$ & $56.2(18)$ \\
\hline
\end{tabular}

Source: Field Data (2018)

As presented on table 3 above, 100\% of respondents declared that NSSF management set clear employee goals for pension payment. Furthermore $96.9 \%$ of respondents admitted that NSSF embraces a two way communication style while $96.9 \%$ agreed that NSSF management delegates responsibilities to subordinates. $93.8 \%$ of respondents agreed that management 
provides rewards or motivations to performing employees while $90.6 \%$ agreed that NSSF employees' are involved in decision making. 56.2\% of respondents agreed that management encouraged poor performing employees through incentives and mentorship while $40.7 \%$ disagreed to the statement.

It is factual that the two way communication style has a positive impact on performance and when employed by managers, it improves relationships and the flow of information between subordinates and managers. Employees can openly discuss their problems and also provide suggestions to their management for better performance of employees. The top management can easily get feedback from employees for non - financial and financial activities in the organization. Such motivation is possible only through two way communication which leads to higher job satisfaction among employees.

\subsection{Effectiveness of Pension Payment Management}

It was imperative to obtain respondents' opinion on the effective of NSSF pension payment management and findings are as presented on Table 4 below;

Table 4 The Effectiveness of Pension Payment Management

\begin{tabular}{|c|c|c|c|c|c|c|c|}
\hline $\begin{array}{l}\text { Effectiveness of } \\
\text { Pension Payment } \\
\text { Management }\end{array}$ & $\begin{array}{l}\text { Strongly } \\
\text { Disagree }\end{array}$ & Disagree & $\begin{array}{c}\text { Cumulative } \\
\text { Disagree }\end{array}$ & Neutral & Agree & $\begin{array}{c}\text { Strongly } \\
\text { Agree }\end{array}$ & $\begin{array}{c}\text { Cumulative } \\
\text { Agree }\end{array}$ \\
\hline Item & Per(Frq) & Per (Frq) & Per (Frq) & Per(Frq) & $\begin{array}{c}\text { Per } \\
\text { (Frq) }\end{array}$ & Per (Frq) & Per (Frq) \\
\hline $\begin{array}{l}\text { Customers } \\
\text { served per day } \\
\text { increase }\end{array}$ & $0.0(0)$ & $0.0(0)$ & $0.0(0)$ & $6.3(2)$ & $25.0(8)$ & $68.8(22)$ & $0.0(0)$ \\
\hline Minimize errors & $0.0(0)$ & $3.1(1)$ & 3.1(1) & $6.3(2)$ & $25.0(8)$ & $65.6(21)$ & $90.6(28)$ \\
\hline $\begin{array}{l}\text { Effectiveness of } \\
\text { Pension Payment } \\
\text { Management }\end{array}$ & $\begin{array}{l}\text { Strongly } \\
\text { Disagree }\end{array}$ & Disagree & $\begin{array}{c}\text { Cumulative } \\
\text { Disagree }\end{array}$ & Neutral & Agree & $\begin{array}{c}\text { Strongly } \\
\text { Agree }\end{array}$ & $\begin{array}{c}\text { Cumulative } \\
\text { Agree }\end{array}$ \\
\hline $\begin{array}{l}\text { Customers' } \\
\text { satisfaction }\end{array}$ & $0.0(0)$ & $0.0(0)$ & $0.0(0)$ & $6.3(2)$ & $28.1(9)$ & $65.6(21)$ & $90.7(30)$ \\
\hline $\begin{array}{l}\text { Reduction of } \\
\text { complaints }\end{array}$ & $0.0(0)$ & $6.3(2)$ & $6.3(2)$ & $3.1(1)$ & $18.8(6)$ & $71.9(23)$ & $90.7(29)$ \\
\hline Fraud is detected & $0.0(0)$ & $0.0(0)$ & $0.0(0)$ & $0.0(0)$ & $31.3(10)$ & $68.8(22)$ & $100(32)$ \\
\hline $\begin{array}{l}\text { Accurate } \\
\text { computation of } \\
\text { payment }\end{array}$ & $0.0(0)$ & $0.0(0)$ & $0.0(0)$ & $0.0(0)$ & $37.5(12)$ & $62.5(20)$ & $100(32)$ \\
\hline $\begin{array}{l}\text { Easy payment } \\
\text { computation }\end{array}$ & $0.0(0)$ & $0.0(0)$ & $0.0(0)$ & $0.0(0)$ & $31.3(10)$ & $68.8(22)$ & $100(32)$ \\
\hline $\begin{array}{l}\text { Timely issuing } \\
\text { Payment }\end{array}$ & $0.0(0)$ & $0.0(0)$ & $0.0(0)$ & $6.3(2)$ & $25.0(8)$ & $68.8(22)$ & $93.8(30)$ \\
\hline
\end{tabular}

Source: Field Data (2018)

As presented on table 4, $100 \%$ of respondents declared that frauds are effectively detected and agreed to accuracy in payment computation. Furthermore $100 \%$ of respondents agreed that pension payment computations at NSSF were easy while $93.7 \%$ agreed that the number of customers served daily at NSSF was on the increase, customers were satisfied and pension payments were promptly issued. Moreover $90.6 \%$ also agreed with the statement that the low error in services provided consequently decreased the number of complaints. 


\subsection{Multiple Linear Regression Analysis Technique}

Multiple Linear Regression Analysis technique employed as a Test of hypotheses by using Effectiveness of Pension Payment Management as the outcome variable and the variables Use of ICT, Quality of Staff, and Management Style as predictors. Expected that better performance of the Effectiveness of Pension Payment Management be associated with highly Use of ICT, higher Quality of Staff and fair and friendly Management Style.

That means: if the significance level (p-value) is very small (less than 0.005) then the variables were significant and the two variables were linearly related. The coefficients of explanatory variables show the magnitude in which each influence the dependent variable. Here below is the model representing the Multiple Linearity Regression equation and results from SPSS:-

$$
\mathrm{Y}=\alpha+\beta_{1} \text { UseofICT },+\beta_{2} \text { Staffs' quality }+\beta_{3} \text { ManagementStyle }+\varepsilon
$$

Table 5 below showing regression analysis results from SPSS

\begin{tabular}{|c|c|c|c|c|c|c|c|c|c|c|c|}
\hline \multicolumn{12}{|c|}{ Table 5: Multiple Linear Regression Coefficients } \\
\hline \multirow{2}{*}{\multicolumn{2}{|c|}{ Model }} & \multicolumn{2}{|c|}{$\begin{array}{c}\text { Unstandardized } \\
\text { Coefficients }\end{array}$} & \multirow{2}{*}{$\begin{array}{c}\begin{array}{c}\text { Standardized } \\
\text { Coefficients }\end{array} \\
\text { Beta }\end{array}$} & \multirow[t]{2}{*}{$\mathrm{T}$} & \multirow[t]{2}{*}{ Sig. } & \multicolumn{2}{|c|}{$\begin{array}{c}95.0 \% \text { Confidence } \\
\text { Interval for B }\end{array}$} & \multicolumn{3}{|c|}{ Correlations } \\
\hline & & B & Std. Error & & & & $\begin{array}{l}\text { Lower } \\
\text { Bound }\end{array}$ & $\begin{array}{l}\text { Upper } \\
\text { Bound }\end{array}$ & $\begin{array}{l}\text { Zero- } \\
\text { order }\end{array}$ & Partial & Part \\
\hline \multirow{4}{*}{1} & (Constant) & 3.036 & 7.691 & & .395 & .018 & -12.719 & 18.792 & & & \\
\hline & ICT & .271 & .177 & .239 & 1.527 & .003 & -.092 & .634 & .385 & .277 & .217 \\
\hline & QS & .631 & .176 & .560 & 3.580 & .001 & .270 & .991 & 619 & .560 & .509 \\
\hline & MS & -.019 & .244 & -.013 & -.080 & .126 & -.518 & .480 & .305 & -.015 & -.011 \\
\hline
\end{tabular}

Source: Field data, (2017)

As per cross tabulation the multiple linear regression equation is defined as $\mathrm{Y}=3.036+0.271 \mathrm{X}_{1}+\mathbf{0 . 6 3 1} \mathrm{X}_{2}-0.019 \mathrm{X}_{3}+\varepsilon$. The MLR coefficients were interpreted as follows: -

Decision and Conclusion: Focus on the three predictors, whether they are statistically significant or insignificant and, the direction of the relationship. The Use of ICT, $\beta_{1}=+0.271$ is statistically significant since calculated $p$-value is less $(\mathrm{p}=0.003)$ than the critical $p$-value $(p=0.005)$, and the coefficient is positive $(0.271)$ which would indicate that a one unit change in Use of ICT, is related to the increase of the effectiveness of pension payment management by 0.271level. As we would expect that the increases Use of ICT result to the increase of effectiveness of pension payment management or performance in any organization. Next, Quality of Staff $\left(\beta_{2}=+0.631, p=.001\right)$ is significant and its coefficient is positive indicating that the greater the Quality of Staff hired, related to the greater the effectiveness of pension payment management. Thus, higher levels of Staff Quality are associated with higher the effectiveness of pension payment management. This result also makes sense. Finally, the Management Style $\left(\beta_{3}=-0.019, \mathrm{p}=.126\right)$ seems to be unrelated to the effectiveness of pension payment management. The findings would seem to indicate that the Management Style is not an important factor in predicting the effectiveness of pension payment management; since calculated p-value is greater $(\mathrm{p}=0.126)$ than the critical $\mathrm{p}$-value $(\mathrm{p}=0.005)$. This result was somewhat unexpected.

Both Pearson Correlation Coefficient and Multiple Linear Regression Analysis Techniques as were employed to test hypotheses of the study all the converged at the same answer, that there is statistic significant between Use of ICT, and Quality of Staff on Effectiveness of Pension Payment Management and statistic insignificant between Management Style and Effectiveness of Pension Payment Management 


\section{Conclusion}

The study concludes that use of ICT less required for the effectiveness of pension payment management but according to response of the respondents as presented in findings, it is implying that use of ICT it is very virtue on influence the effectiveness of pension payment management because responds had positive altitude (agreed) on the function of ICT such as database management, Fraud detection, Cost reduction, and quickly service delivery about $96.9 \%$ of respondents agreed, Easily pension processing and new ways of communication about $93.8 \%$ of responds agreed and finally about $84.4 \%$ of respondents agreed that the prompt feedback through using ICT. However; the Administers should keep on emphasizing the use of ICT and proper use of it through provision of training to employees whose are unfamiliar with the ICT system and keeping improving system to move with new version. Also study concludes that to large contribution made by staff quality on the effectiveness of pension payment management more than half of total effectiveness about 0.631 .

Multiple Linear Regression resulted as B=-0.019, 0.126 greater than 0.05 is insignificance related to the effectiveness on pension payment management. These results are contrary to the respondents' response, i.e. management style which is defined in this study as presented above $100 \%$ of respondents declared that NSSF management set clear employee goals for pension payment. Furthermore $96.9 \%$ of respondents admitted that NSSF embraces a two way communication style and delegates responsibilities to subordinates (mutual trust). $93.8 \%$ of respondents agreed that management provides rewards or motivations to performing employees while $90.6 \%$ agreed that NSSF employees' are involved in decision making. $56.2 \%$ of respondents agreed that management encouraged poor performing employees through incentives and mentorship while $40.7 \%$ disagreed to the statement. By using these results administrators should practice fairly and involvement management style because had positive response to the respondents on the effectiveness of pension payment management an expected to have positive influence on the performance in any other organization.

\section{References}

Ako. (2006). Contributory Pension Schemes: The case of Brazil. Brazil Pension Guide number 30.

Cassell, C (2001). Managing Diversity. Contemporary Human Resources Management, 404-431

Dagauda et al. (2013). an analysis of the impact of the 2004 pension policy on the welfare of the nigerian civil servants: a case study of selected federal ministries:. Global Journal of Human Resource Management, 1, 20- 55.

Dagauda et al. (2013). An Analysis Of The Impact Of The 2004 Pension Policy On The Welfare of the NigerianCivil Servants

Kazimoto P and Mhindi G (2012) Analysis of Retirement Benefits and Social-Economic Development in Retirees in Tanzania. Unpublished research, University of Arusha.

Okoli et al. (2012). Information of Communication Technology on the Influence Performance of Secretaries in Government Ministries in Nasarawa State, North-Central Nigeria. Research Journal of Information Technology, 93-97.

Namusong et al. (2012). The Effect of Leadership Styles on Organizational Performance at State Corporations in Kenya:. International Journal of Business and Commercde, 2, No1:, 01 - 12.

Nwadukwe, U. C. (2012). Management Styles and Organizational Effectiveness: An Appraisal of Private Enterprises in Eastern Nigeria:. American International Journal of Contermporary Research, 2 No. 9. 